\title{
Goth Comics and Revisionist Fairytales
}

\author{
Laurie N. Taylor
}

Valentino, Serena (writer), FSc (artist, letterer), and Joshua Archer (letterer). Nightmares and Fairytales Volume One: Once Upon a Time... (Graphic Novel Collection of Issues 1-6). San Jose, CA: Slave Labor Graphics Publishing, March 2004. ISBN: 0-943151-87-2.

Nightmares and Fairytales Volume One, by writer Serena Valentino and artist FSc, collects the first six issues of the Goth comic Nightmares and Fairytales. While many Goth comics_-including Valentino's Gloomcookie-are situated more fully within a Goth comics tradition by focusing mainly on Goth culture, Nightmares and Fairytales is oriented more generally within a revisionist tradition that blends in elements from Goth culture. By focusing on revisionist tales, Nightmares and Fairytales operates within a rich comics' tradition of revisions and retellings like the constant remakings of particular superhero origination stories, the more faithful adaptations of classics in works like Classics Illustrated, and the revisionist versions of existing fairy and folk tales like those currently found in Fables.

Framing the beginning of Nightmares and Fairytales Volume One and returning in various comics throughout the series is Annabelle, a magical doll who aids in guiding the reader through the revisions and aids or hinders the protagonists in several issues. The first stories fall more in line with traditional Goth comics, which tend to focus on Goth cultural representations of dystopian world views with Laurie N. Taylor, PhD candidate at the University of Florida, has published articles in Game Studies, Works and Days, and ImageTexT: Interdisciplinary Comics Studies, and has forthcoming articles in several collections on video games. 
magical influences. Goth comics of this sort are often viewed as beginning with Jhonen Vasquez's Johnny the Homicidal Maniac and his subsequent comic Squee. With their success, other Goth comics like Gloomcookie, Lenore, Outlook Grim, Bear, and Serenity Rose quickly followed. Visually, Goth comics are defined by their style which draws on graffiti and manga-influenced art styles. Often the comics are only in black and white or dark muted colors, and they often rely on dark, sketchy lines for objects. Similarly, the lettering is generally written in sketchy lines or gothically decorated semi or full cursive. Like typical Goth comics, the first stories in Nightmares and Fairytales use the dystopian setting to focus on a somewhat realistic tale of the troubled relationship between Morgan, an innocent young woman, and her lover Dominique. The comic quickly shows Dominique to be an actual monster, but a monster who is humanized through her suffering created by the demented and occult world in which she and Monique exist. This story operates in a similar manner to many fairytales, but it does not present a revisionist fairytale as such.

The subsequent stories are more typically revisionist. One retells the story of Snow White (this time with Snow surviving the removal of her heart by the Queen's huntsman and killing the Queen); another reworks the story of Cinderella; and another features a modern day version of a child-escape fairytale. The retelling of Cinderella proves interesting because Cinderella, as in many of the earlier tales, is abused by her step-mother and step-sisters. However in this story, Cinderella's prince is also evil and Cinderella luckily manages to escape him through her stepfamily's evil deeds. In the end, Cinderella escapes both her family and marriage, a route not often offered even in revisionist tales. The child-escape tale is a twist on the traditional child fleeing from monsters. In it, a young girl named Gwen is saved from her abusive parents by the benevolent monsters in her closet. The monsters kill her parents so that Gwen can move in with a kind caretaker. In both of these stories, Annabelle narrates and assists. With Annabelle as part of the frame story, and with each of the revised fairytales taking a decidedly feminist bent, Nightmares and Fairytales utilizes revisionist tales in order to rewrite traditional tales in which women are oppressed. Later issues repeatedly revise the role of women in fairytales to further empower women and to shift typical gender power structures with stories like a revisionist version of Beauty and the Beast that tells a love story between two young women.

Goth comics like the first volume of Nightmares and Fairytales provide an important entry into mainstream comics. They do so by presenting tales that rewrite the traditional comics trajectory by including tales that feature women main characters who are presented in visually non-hypersexualized ways due to the art style of Goth comics. Through marketing - with Goth comics available in book stores, comic shops, and Goth clothing stores like "Hot Topic"-and through its stories, Nightmares and Fairytales manages to both revise typical fairytales while also allowing for a revision of women in and women reading comics. Goth comics are also important for mainstream comics because they prove that a market exists for non-superhero, yet still fantastically-based comics and they provide a method by which to access that audience. 
With the emergence of manga as a major form, the comics market for girls and young women has grown inordinately in the past few years. However, fewer comics made in the United States have been able to capitalize on this new market and new audience in the manner that Goth comics have because Goth comics present a median style that reflects elements of both traditional superhero and manga styles. Furthermore, Goth comics serve as an intermediate form between the typical superhero and Disney comics and their adult-oriented counterparts like the comics from Vertigo and documentary style comics like Joe Sacco's Palestine and Marjane Satrapi Persepolis. Given Goth comics' focus on teen-related issues, often told within fairy tale landscape and dark humor, Goth comics may serve as a bridge from the comics typically given to children to the more sophisticated comics that are readily available. In all, Goth comics exist on the outskirts of the mainstream comics creation and reception. However, their border placement grants the ability to diverge from typical comics art styles and production. This in turn may feed back into more mainstream comics to facilitate new art styles, new readers, and new narratives for mainstream comics. In the meantime, Goth comics titles continue to proliferate and earn larger audiences. 